\title{
ブランチした甘藷の品種と糖化率 \\ Varieties of blanched Sweet-potatoes and their \\ Saccharification Degree
}

（昭和 27 年 9 月 3 日受理）

\section{大宮 滿 男 \\ (Mitsuo Oomiya)}

\section{緒言}

ブランチング (Blanching) については前報で詳詨し

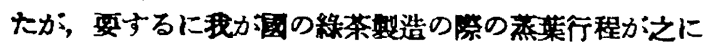

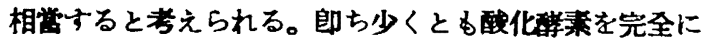

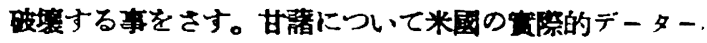

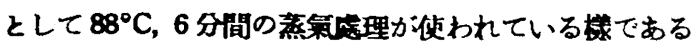

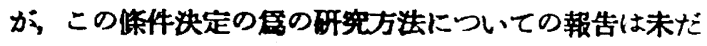

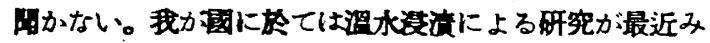
られる域である。著者は甘籍についてブランチングとア ミラーゼとの睹について多少の知見を得たので前報で 共に報告した。

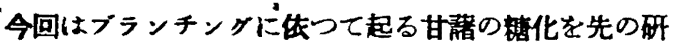

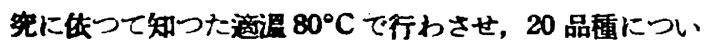
てその期化本を比较し，䋇30１0\%の開きのある事を

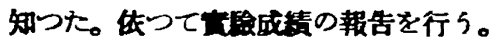

\section{實硻の部}

\section{1. 些证方法}

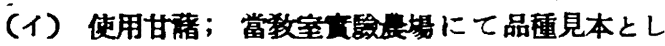
て藏培したるのを，7/XII，1951 に掘取り，常法により 7/XII，1951 より14/III，1952まで土密に聍藏したもの

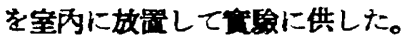

(口) 試枓；各品璉平均 10 ケ宛の健全で，中等度の

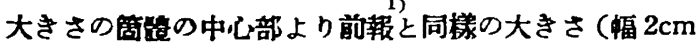
長さ $5 \mathrm{~cm}$ 及び厚さ $0.5 \mathrm{~cm}$ ) に庖丁にて切断したるのよ

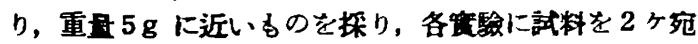
を使用し，その平均值を計算に使用した。

（ハ）ブランチング；等四及び方法の大要は前報と 同檥で $80^{\circ} \mathrm{C} ， 6$ 分間の條件を用いたが，今回は蒸気發生 裝置として電氣定溫晹煎器 (島津製, $100 \mathrm{~V} ; 600 \mathrm{~W}$, 徑 粎 $18 \mathrm{~cm}$, 切片 11 ケ掛のすの)を使用した(Fig..1.)。又 切片を挿入してから塞暖計の示度が $80^{\circ} \mathrm{C}$ になる迄の時 間を測定したか，平均1分 30 秒であつた。

* フランチングに睄する碚，第 2 報 (Studies on Blanching. Part 2).
（）糖分定量；ブランチ前及び後の切片各 1 ケに

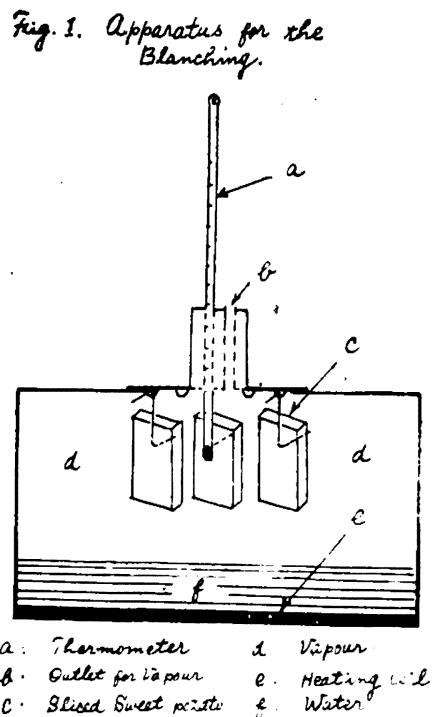

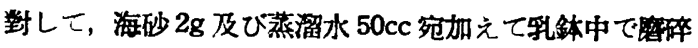
し，150cc 三角フラスコに入れ，トルオール1〜2滴加え ゴム栓で密栓し，唒溫器に入れ抽出した（抽出條件につ

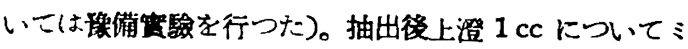
クロベルトラン氏法に恢り生成糖を定量し，グルコース の $\mathrm{mg}$ にて現わした。

（ホ）糖化本； 上記碎碎液各々に $25 \% \mathrm{HCl} 10 \mathrm{cc,}$ 蒸溜水 $40 \mathrm{cc}$ 宛加え, 沸瞈浴中で 1 時間分解した液につ い二前と同樣にして切片の全糖を求めた。做用した計算 式は次の通りである。

(After Blanch-Before Blanch) Sugar as glucose Total sugar as glucose $\times 100=$ Sáccharification Degrel (\%)

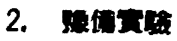

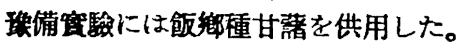

（1）抽出溫度の影坛； $30^{\circ}, 40^{\circ}, 50^{\circ}$ 及び $60^{\circ}$ につ き試驗した。結果は:Table 1. の如し。

抽出に高溫を使用する程，糖分测定値が大となつた。 之は抽出中に糖化が起つた爲と思われる。此の點フラ 
ンチ後のものは器つていた。故に抽出温度としては报低 の $30^{\circ} を$ 沶用した。

Table 1. Effect of Extraction

Temperature

\begin{tabular}{c|r|r|r|r|r}
\hline Datum & $\begin{array}{c}\text { Extr- } \\
\text { action } \\
\text { Temp } \\
(1952)\end{array}$ & $\begin{array}{c}\text { Before } \\
\text { Blanch } \\
\text { as } \\
\text { glucose } \\
\mathrm{mg}\end{array}$ & $\begin{array}{c}\text { After } \\
\text { Blanch } \\
\text { as } \\
\text { glucose } \\
\mathrm{mg}\end{array}$ & $\begin{array}{c}\text { Total } \\
\text { Sugar } \\
\text { as } \\
\text { glucose } \\
\mathrm{mg}\end{array}$ & $\begin{array}{c}\text { Sacchar- } \\
\text { ification } \\
\text { Degree } \\
(\%)\end{array}$ \\
\hline 14/ I & 30 & 83.6 & 394 & 1,199 & 25.8 \\
18/ I & 40 & 98.8 & 442 & 1,382 & 24.8 \\
21/ I & 50 & 155.0 & 452 & 1,234 & 23.9 \\
Do. & 60 & 406.0 & 464 & 1,270 & 4.6 \\
\hline
\end{tabular}

Extraction Duration: 4 hrs.

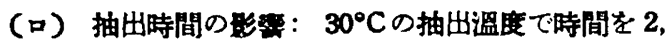
6 及び 13 時間と妏えてみたが，2時間の场合 13 時間の 保件に一致する值か得られたので，本殓に於ては之を

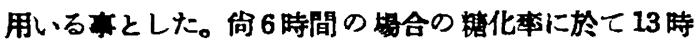
间より大なる枯果か出たが之については釟討しなかつ た。結果は Table 2. の如し。

Table 2. Effect of Extraction Duration

\begin{tabular}{l|r|r|r|r|r}
\hline -Datum & $\begin{array}{c}\text { Extr- } \\
\text { action } \\
\text { Duration } \\
\text { (hrs.) }\end{array}$ & $\begin{array}{c}\text { Before } \\
\text { Blanch } \\
\text { as } \\
\text { glucose } \\
\text { mg }\end{array}$ & $\begin{array}{c}\text { After } \\
\text { Blanch } \\
\text { as } \\
\text { glucose } \\
\text { mg }\end{array}$ & $\begin{array}{c}\text { Total } \\
\text { Sugar } \\
\text { as } \\
\text { glucose } \\
\text { mg }\end{array}$ & $\begin{array}{c}\text { Scchar- } \\
\text { ification } \\
\text { Degree } \\
\text { (\%) }\end{array}$ \\
\hline $25 / I$ & 2 & 70.0 & 372 & 1,287 & 23.4 \\
$14 /$ I & 4 & 98.8 & 394 & 1,199 & 25.8 \\
$25 /$ I & 6 & 85.0 & 412 & 1,114 & 29.3 \\
$27 /$ I & 12 & 124.0 & 446 & 1,399 & 23.0 \\
\hline
\end{tabular}

Extraction Temp.: $30^{\circ} \mathrm{C}$

\section{3. 木面}

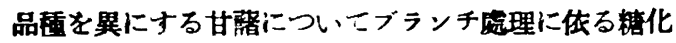
率を求めた。結果は Table 3. の如し。

甘瑟のアミラーゼは咛藏中はその作用が餘り基化しな

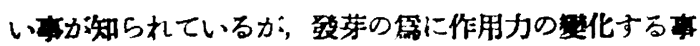

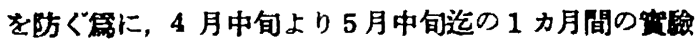
によつて得られたすのの値を堔一た。品徝による棈化本

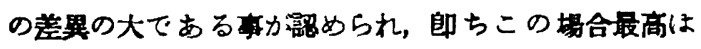
$29.3 \%$ ，最低は $10.0 \%$ を示し，源氏及び人唯 (年人藉) は最高の部類であつた。

\section{考察}

本交驗に侬つて得られた糖化斩は,・ブランチングに依 つて影受けた甘藉中のアミ゙ラーゼが，料化された自 己の没妢に作用した絬果出て來たすのであると推定され

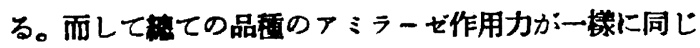

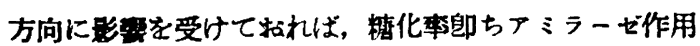
カと見なして良いであろら。この點に的しては更に援討 ナる伐要があると思5。
Table 3. Varieties of Blanched

Sweet-potatoes and their

Saccharification Degree

\begin{tabular}{|c|c|c|c|c|c|}
\hline $\begin{array}{l}\text { Datum } \\
\text { (1952) }\end{array}$ & Varieties & $\begin{array}{l}\text { Before } \\
\text { Blanch } \\
\text { as } \\
\text { glucose } \\
\text { mg }\end{array}$ & $\begin{array}{c}\text { After } \\
\text { Blanch } \\
\text { as } \\
\text { glucose } \\
\text { mg }\end{array}$ & $\begin{array}{c}\text { Totar } \\
\text { Sugar } \\
\text { as } \\
\text { glucose } \\
\text { mg }\end{array}$ & $\begin{array}{l}\text { Socchar- } \\
\text { ification } \\
\text { Degree } \\
(\%)\end{array}$ \\
\hline $11 / \mathrm{IV}$ & $\underset{\text { Genji }}{\text { 源 }}$ & 70.0 & 414.0 & 1173. & 29.3 \\
\hline Do. & $\begin{array}{l}\text { Tsurunas- } \\
\text { hi-Genji }\end{array}$ & 96.0 & 375.0 & 1351. & 20.6 \\
\hline $16 / \mathrm{IV}$ & $\begin{array}{c}\text { 㤟林 } 1 \text {. } \\
\text { Norin No.1 }\end{array}$ & 61.8 & 362.0 & 1520. & 19.8 \\
\hline Do. & $\begin{array}{c}\text { W } 2 \\
\text { NorinNo.2 }\end{array}$ & 47.0 & 309.0 & 1475. & 17.8 \\
\hline $21 / \mathrm{IV}$ & $\begin{array}{c}\text { 林 } 3 \\
\text { Norin No.3 }\end{array}$ & 57.8 & 356.0 & 1625. & 18.3 \\
\hline Do. & $\begin{array}{l}\text { 晨林 } \\
\text { Norin }\end{array}$ & 102.8 & 229.5 & 1269. & 10.0 \\
\hline $23 / \mathrm{IV}$ & $\begin{array}{l}\text { Not } 5 \text { 號 } \\
\text { Norin No.5 }\end{array}$ & 103.0 & 357.0 & 1452. & 17.7 \\
\hline Do. & $\begin{array}{c}\text { Wer } 652 \\
\text { Norin No.6 }\end{array}$ & 110.0 & $\mathbf{3 4 7 . 0}$ & 1307. & 18.1 \\
\hline $26 / \mathrm{IV}$ & \begin{tabular}{|} 
林 7 \\
Norin No.7
\end{tabular} & 138.3 & 341.0 & 1137. & 17.9 \\
\hline Do. & $\begin{array}{c}\text { 林 } 8 \text { 竝 } \\
\text { Norin No.8 }\end{array}$ & 84.5 & 326.5 & 1206. & 20.1 \\
\hline 30/IV & $\begin{array}{c}\text { 林 } 9 \text { 號 } \\
\text { Norin No.9 }\end{array}$ & 135.0 & $\mathbf{3 7 9 . 0}$ & 1275. & 19.1 \\
\hline Do. & $\begin{array}{c}\text { 岩手 } 2 \text { } \\
\text { Iwate No.2 }\end{array}$ & 102.0 & 273.0 & 1159. & 14.8 \\
\hline $1 / \mathrm{V}$ & $\begin{array}{l}\text { 高系 } 3 \text { 期 } \\
\text { Kokei No.3 }\end{array}$ & 75.8 & 257.0 & 1305. & 13.9 \\
\hline Do. & $\begin{array}{c}\text { 東 } 3 \text { 虎 } \\
\text { Kanto No.3 }\end{array}$ & 72.3 & 371.0 & 1499. & 19.9 \\
\hline $6 / V$ & (营赤)南瓜 & 121.8 & 361.0 & 1209. & 19.8 \\
\hline Do. & $\begin{array}{l}\text { Ninjin } \\
\text { 九州10 }\end{array}$ & 100.8 & 470.0 & 1355. & 27.2 \\
\hline $12 / \mathrm{V}$ & $\begin{array}{c}\text { Kyushu } \\
\text { No. 10 } \\
\text { 九 6-880 }\end{array}$ & 67.0 & 269.0 & 1536. & 13.2 \\
\hline Do. & $\begin{array}{c}\text { Kyukei } \\
6-880 \\
\end{array}$ & 47.8 & 384.0 & 1404. & 23.9 \\
\hline $14 / V$ & $\begin{array}{c}\text { Okinawa } \\
\text { Asahi } \\
\text { 九州 } 8\end{array}$ & 73.5 & 475.0 & 1482. & 27.1 \\
\hline Do. & $\begin{array}{l}\text { Kyushu } \\
\text { No. } 8\end{array}$ & 58.3 & $\mathbf{4 2 8 . 0}$ & 1477. & 25.0 \\
\hline
\end{tabular}

\section{要 約}

20 品㲧の甘藉にブランチ庭理に依る楉化率を求めた 所, 粎 30〜10\%の開きのあることを認めた。

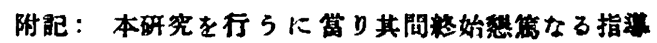

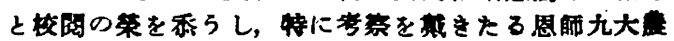

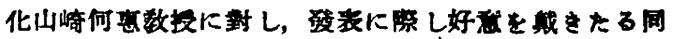

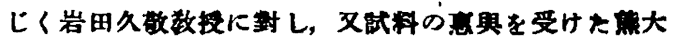

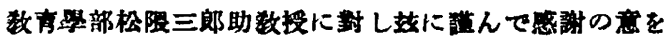
表す。

(熊本大學数高祭部)

$$
\text { 文䭾 }
$$

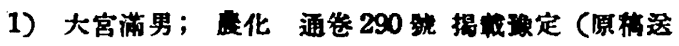
附昭和 26 年 12 月 11 日)。 